\title{
СУЧАСНІ ПСИХОТЕХНОЛОГІЇ
}

\author{
https://doi.org/10.34142/23129387.2020.62.15 \\ UDC 159.9:378.048.4(043.3/.5) \\ ORCID 0000-0002-5085-8895
}

\section{SOCIOPSYCHOLOGICAL ASPECTS OF IMPLEMENTATION OF THE PROFESSIONAL READAPTATION OF PERSONALITY}

\author{
Panov Nikita Serhiovych, \\ Ph. D. in Psychology, Associate Professor of the Department \\ of Special Pedagogy and Special Psychology \\ Municipal Institution of Higher Education \\ "Khortytsia National Educational Rehabilitation Academy" \\ of Zaporizhzhia Regional Council \\ E-mail: nikita.psyhol@ukr.net
}

The Aim of the article is to determine the socio-psychological features of the personality's professional re-adaptation in modern society (on the example of the unemployed belonging to internally displaced persons).

Methods. The study used a set of empirical methods (observations, surveys, interviews, discussions, the method of expert assessment, the study of the civic and volunteer organizations' documentation) as well as theoretical theoretical methods (the analysis of scientific publications, programs of support for internally displaced persons, comparison of the obtained data and scientific perspectives, generalization and systematization of the obtained results).

Results. It was found out that the unemployed that belong to the category of the internally displaced persons are living though a number of crises due to the external and internal factors, they experience difficulties in adapting to the new socio-economic conditions, and are characterized by a passively expectant attitude. The necessity of providing the internally displaced persons with psychotherapeutic assistance and professional psychologic consultations of specialists with the aim of overcoming crisis situations is substantiated. 
It was determined that professional readaptation is an indicator of the state personnel policy's success and, as such, a catalyst for the processes of the personnel's selecting, training, retraining and employment. It was found out that a number of state, regional and oblast programs, as well as social and psychological studies were focused on the psychological support of the internally displaced persons. The above mentioned issue had been the focus of a number of volunteer organizations, whose activities were characterized by the absence of a comprehensive systematic approach and the lack of efficient specialists.

Conclusions. Professional readaptation is a gradual adaptation of a person already having an experience of professional activity to his/her new conditions, in the course of which takes place the restructuring of the personality's need-and-motivational sphere. The harmonious relationship between the personality's adaptive potential and the new conditions of professional activity is viewed as an indicator of effective professional readaptation.

The effectiveness of such forms and methods of psychological support as special trainings, game technologies, aimed at overcoming the personality's depressive states, enhancing his/her self-confidence, stimulating personal and professional development is proved.

Keywords: internally displaced persons, unemployed, social readaptation, programs, methods, trainings

\section{Соціально-психологічні аспекти забезпечення професійної реадаптації особистості Микита С. Панов}

кандидат психологічних наук, дочент, доиент кафедри спеиіальної педагогіки та спеціальної психології, Комунальний заклад вищзої освіти «Хортицька національна навчально-реабілітаційна академія» Запорізької обласної ради

Мета статті - визначити соціально-психологічні особливості професійної реадаптачії особистості в сучасному соиіумі (на прикладі безробітних, щя належать до внутрішньо переміщених осіб).

Методи. У дослідженні використано комплекс емпіричних (спостереження, анкетування, інтерв'ювання, бесіди. метод експертних оцінок, вивчення документації громадських $i$ 
волонтерських організацій) і теоретичних (аналіз наукових публікацій, програм підтримки внутрішньо переміщених осіб, порівняння отриманих даних $і$ наукових поглядів, узагальнення й систематизація результатів) методів.

Результати. 3'ясовано, що безробітні, що належать до категорії внутрішньо переміщених осіб, переживають низку кризових станів, зумовлених зовнішніми і внутрішніми чинниками, відчувають труднощзі під час адаптації до нових соиіально-економічних умов, їм притаманна пасивно-очікувальна позичія. Обтрунтовано необхідність надання внутрішньо переміщеним особам психотерапевтичної допомоги та професійних консультацій фахівців-психологів для подолання кризових життєвих ситуацій.

Визначено, щзо професійна реадаптація $\epsilon$ показником успішності державної кадрової політики, а відповідно, $i$ каталізатором процесів відбору, підготовки, перепідготовки $i$ працевлаштування кадрів. Виявлено, щзо на психологічну підтримку внутрішньо переміщених осіб спрямовано низку державних, регіональних і обласних програм, а також сочіально-психологічних досліджень. Зазначена проблема перебувала в иентрі уваги низки волонтерських організаиій, діяльність яких характеризувалася відсутністю комплексного системного підходу й браком компетентних фахівиів.

Висновки. Професійна реадаптаиія - ие поступове пристосування особистості, щзо вже має досвід професійної діяльності, до ї̈ нових умов, при якому відбувається перебудова потребово-мотиваиійної сфери особистості. Показником ефективної професійної реадаптації є гармонійні відносини між адаптаційним потенціалом особистості й новими умовами професійної діяльності.

Доведено ефективність таких форм і методів психологічної підтримки, як спеціальні тренінги, ігрові технології, метою яких $\epsilon$ подолання депресивних станів особистості, посилення ії впевненості в собі, стимулювання особистісного і професійного розвитку.

Ключові слова: внутрішньо переміщені особи, безробітні, соиіальна реадаптаиія, програми, методи, тренінги.

\section{Introduction}

As of today the professional activity of the personality is one of the main ways of its self-realization. Crisis phenomena at the state and public levels (military activities in East Ukraine, labor and 
educational migration, changes in priorities in the production and intellectual spheres, processes of informatization and technologicalization) perform a controversial role in human life: they either stimulate its activity and constructive development as individuals and specialist, or lead to disadaptation. At the same time, the action of external factors correlates with a whole range of qualities that make up the adaptive potential of a person. Considering political or social factors, people left unemployed often show an unwillingness to adequately solve the problems of professional arrangement in new place or new conditions. In the context of these trends, a separate direction of interdisciplinary research has emerged - psychology of professional rehabilitation, whose representatives rely on data in scientific searches from various fields of scientific knowledge, in particular: sociology and economics, physiology, as well as labor psychology, psychology of personal development and social psychology.

Consequently, the problem of professional readaptation is a relatively new area of socio-psychological research, which has gained particular relevance in the face of the emergence of a large number of internally displaced people who are forced to adapt to life in new socio-cultural conditions, a situation of cardinal changes in priorities in social and industrial relations. In general, researchers turned to the study of the peculiarities of professional rehabilitation of certain social groups, for example, participants in hostilities (N. Dmitrieva, L. Shestopalova); persons who returned from prisons (T. Tatidinova, V. Trubnikov). Over the past years, a number of studies have appeared in the scientific community of Ukraine related to the social adaptation of forced emigrants (O. Blinova, I. Drozdova). However, today both theoretical and methodological, as well as practical and implementation aspects of the professional readaptation of the unemployed relating to internally displaced people remain underdeveloped. Therefore, the aim of the article is to determine the sociopsychological characteristics of professional readaptation of a person in modern society (on the example of the unemployed, related to internally displaced persons). The purpose of the article made it possible to formulate the following research tasks: to analyze the 
scientific views on the problem of professional rehabilitation; to investigate the state of psychological support of internally displaced persons at the present stage; identify effective forms and methods of psychological support of the internally displaced unemployed persons.

Professional readaptation is considered as a gradual adaptation of workers who already have work experience in new conditions of professional activity (social relations, professional duties, physical working conditions, production tasks and operations), in which there is a restructuring of the need-motivational sphere of the personality. L. Vallo notes that the result of this process should be a harmonious relationship between the adaptive potential of the individual and the new conditions of professional activity (person achieves professional success, reveals its professional potential and maintains mental health) (Vallo, 2017). Therefore, professional reintegration is very important for the integration of internally displaced persons, since it contributes to their entry into the new working collective, the establishment of professional contacts and also one of the main factors for successful social adaptation in the new environment.

Studying industrial readaptation, O. Krushelnytska and D. Melnychuk single out a number of components of this phenomenon, each of which has its own object, tasks, and performance indicators. So, psychophysiological reintegration involves adaptation to new physical and psychological stresses, physiological working conditions. Professional - complete and successful mastery of a new profession, that is, adaptation to the content and nature of labor, its conditions and organization. Sociopsychological - the person's adaptation to a new team, its traditions, the style of leadership. As a result of organizational adaptation, a person occupies an appropriate place in the overall organizational structure, acquires a certain status (Krushelnytska, 2005).

Decisive importance for the professional rehabilitation is the internal potential of the individual, its "starting" conditions. The possibility of employment in general and professional readaptation in particular is a serious problem for internally displaced persons, 
because it is very difficult to find work quickly and adapt to a new professional environment.

O. Blynova specifies two groups of success factors for the social adaptation of migrants in the new sociocultural conditions:

- social (group) factors: circumstances and the nature of migration; family relationships; the availability of social support; establishing contacts with the local population, the presence of friends and acquaintances, the quality of the "social capital" of the migrant; mutual positive perception of immigrants and local residents; state policy aimed at supporting the socio-cultural integration of forced migrants;

- individual factors: age; gender; level of education and social status; personal characteristics (internal localization of control; flexibility and differentiation of self-concept, "cognitive complexity", tolerance of uncertainty, a high level of self-control and self-efficacy; attitude to the application of behavioural strategies of active systematic overcoming of problems and search for social support; attitude to the application of behavioral strategies to new conditions or active impact on them, willingness to change, selfregulation, communicative competence, the ability to change one's value orientations and self-concept, a high level of awareness of the specifics of the new environment) (Blynova, 2016).

Among the conditions ensuring the success of professional readaptation of a personality L. Vallo determined the following:

a) factors related to self-awareness (adequate self-esteem and level of aspirations, faith in yourself, developed reflection, selfesteem, positive self-concept, identification with professionally adapted persons);

b) factors related to the motivational sphere (motivation for achieving success, there is a goal and an adequate plan for its implementation, value orientations);

c) factors of the affective sphere (emotional stability, selfregulation);

d) factors associated with professionally important personality characteristics (professional competence, style of activity, vocation); 
e) factors directly related to general adaptive abilities (activity, willingness to change, etc.) (Vallo, 2017).

I. Baklytsky defines three sets of diagnostic characteristics that are essential for the effectiveness of professional adaptation: the level of emotional stress and resistance to stress; features of microsocial interaction and the degree of adequacy of interpersonal relationships; energy potential and the ability to logically structure the situation (Baklytsky, 2008). Therefore, researchers identify common personality traits inherent among unemployed: a high level of personal and situational anxiety, conformity, pessimism, conservatism, reduced communication skills, isolation, low selfesteem, complicated adaptation to changing working conditions, high rigidity relative to professional preferences (Zauner, 1967). These crisis conditions can be initiated externally or by a person, they are characterized by changes in their psychological state, often in social, professional and material status, accompanied by mental tension and feelings (Gajda, 2015). The vast majority of the unemployed from the list of internally displaced persons are not able to adapt to new socio-economic conditions, they have a passive-waiting position. So, there is a need for psychological support, and then, to create an effective system of professional readaptation of people who have become unemployed as a result of forced internal migration.

Methods and methodology. In the research process, a complex of general scientific and special research methods was used, which ensured the reliability of the results and the objectivity of the formulated conclusions. In particular, in order to generalize and systematize scientific views on the problem of professional rehabilitation of the internally displaced unemployed persons, an analysis of the scientific literature, state, district and regional programs aimed at supporting internally displaced persons, as well as the results of an empirical study, on the basis of which modern scientific and scientific-practical publications on the chosen problem. To find out the effective forms and methods of professional rehabilitation of the internally displaced unemployed persons, a number of empirical methods were used, in particular: questioning of specialists (employees of state authorities, representatives of state, 
public and volunteer organizations, psychologists), who participated in providing support to the internally displaced unemployed persons; interviewing psychologists involved in work with a specified category of the population, monitoring their work; interviews with respondents belonging to internally displaced persons; method of expert assessments (methodology "Map of social adaptation" (for experts) (N. Zavatska), studying data from documentation of local authorities, public and volunteer organizations.

Results and discussions. Professional adaptation is a kind of effectiveness indicator of state policy in the search, selection, retraining of workers, and, accordingly, a catalyst for these processes. At the state level, legislative and regulatory acts were adopted that regulate the rights and obligations of internally displaced persons, in particular, the Law of Ukraine "On Ensuring the Rights and Freedoms of Internally Displaced Persons" (2014), "Comprehensive State Program for the Support, Social Adaptation and Reintegration of Citizens" of Ukraine, who migrated from the temporarily occupied territory of Ukraine and the areas of the antiterrorist operation to other regions of Ukraine for the period up to 2017 "(2015). In addition, programs aimed at the integration, social adaptation and protection of internally displaced persons are operating at the regional and district levels (Table 1).

In some areas there are no targeted programs to protect this category of citizens, but support can be provided as part of programs to help citizens which find themselves in difficult situations. Specialists of local authorities, as well as state and public organizations, charitable foundations were involved in the implementation of the regulations of these programs.

In the context of professional rehabilitation, it is worth mentioning the psychological assistance provided to internally displaced persons by volunteer organizations, primarily in the Kharkiv region («Stantsiya Kharkiv», Tsentr «Pid Arochkoy», «Samarytyany»), in Dnipropetrovsk region (Dopomoha Dnipr, Dopomoha Donbas) in Donetsk region and Lugansk region (SOS Kramators'k, Krayina Vil'nykh Lyudey, SOS Slov'yans'k, Fond Romanovs'koho, 7-a Liniya). 
Table 1

\section{List of existing regional and district programmes aimed at supporting internally displaced persons}

\begin{tabular}{|c|c|c|}
\hline $\begin{array}{c}\text { Region / } \\
\text { district }\end{array}$ & $\begin{array}{l}\text { Program name, links to } \\
\text { Internet resources }\end{array}$ & $\begin{array}{l}\text { Basic regulations on } \\
\text { internally displaced } \\
\text { persons }\end{array}$ \\
\hline $\begin{array}{l}\text { VINNYTSIA } \\
\text { OBLAST }\end{array}$ & $\begin{array}{l}\text { 1. Comprehensive targeted } \\
\text { program of social } \\
\text { protection of the } \\
\text { population of Vinnytsia } \\
\text { oblast for 2019-2021 } \\
\text { https://vinrada.gov.ua/pere } \\
\text { lik_dovgostrokovih_progra } \\
\text { m.htm }\end{array}$ & $\begin{array}{l}\text { Support for integration, } \\
\text { social adaptation, } \\
\text { information and protection } \\
\text { of internally displaced } \\
\text { persons. Providing training } \\
\text { on modern counseling, } \\
\text { escort, interviewing } \\
\text { employees responsible for } \\
\text { working with privileged } \\
\text { categories of the } \\
\text { population (conducting } \\
\text { training seminars, } \\
\text { trainings, focus groups, } \\
\text { workshops, thematic } \\
\text { classes and other forms of } \\
\text { training). }\end{array}$ \\
\hline $\begin{array}{l}\text { ZHYTOMYR } \\
\text { OBLAST }\end{array}$ & $\begin{array}{c}\text { The program of social } \\
\text { support for ATO / OOS } \\
\text { participants, family } \\
\text { members of the lost ATO / } \\
\text { OOS participants, } \\
\text { internally displaced } \\
\text { persons from the } \\
\text { temporarily occupied } \\
\text { territory, areas of the ATO } \\
\text { / OOS on the territory of } \\
\text { the Zhytomyr oblast in } \\
\text { 2020 } \\
\text { https://zt.gov.ua/index.php } \\
\text { /ofitsijni- } \\
\text { dokumenti/oblasni- } \\
\text { programy/perelik- } \\
\text { oblasnykh-program.htm }\end{array}$ & $\begin{array}{l}\text { Providing IDPs with } \\
\text { financial assistance who } \\
\text { found themselves in } \\
\text { difficult life } \\
\text { circumstances; Providing } \\
\text { IDPs with temporary } \\
\text { residence. }\end{array}$ \\
\hline $\begin{array}{l}\text { IVANO- } \\
\text { FRANKIVSK } \\
\text { OBLAST }\end{array}$ & $\begin{array}{l}\text { Regional comprehensive } \\
\text { program of social } \\
\text { protection of the } \\
\text { population of Ivano- } \\
\text { Frankivskoblastfor 2017-2021 } \\
\text { http://rzhradaifualindex.php?id=13 } \\
98\end{array}$ & $\begin{array}{l}\text { Social protection of certain } \\
\text { categories, including } \\
\text { internally displaced } \\
\text { persons. }\end{array}$ \\
\hline
\end{tabular}


Panov N. Sociopsychological aspects of implementation ...

\begin{tabular}{|c|c|c|}
\hline $\begin{array}{c}\text { LUHANSK } \\
\text { OBLAST }\end{array}$ & $\begin{array}{l}\text { Regional targeted program } \\
\text { for support and adaptation } \\
\text { of internally displaced } \\
\text { persons in Luhansk oblast } \\
\text { for } 2017-2018 \\
\text { http://loga.gov.ua/oda/abo } \\
\text { ut/depart/praci/programs/p } \\
\text { rograms/regionalna_cilova } \\
\text { _program_shchodo_pidtri } \\
\text { mki_ta_adaptations }\end{array}$ & $\begin{array}{l}\text { Improving the living } \\
\text { standards of internally } \\
\text { displaced persons, } \\
\text { ensuring their right to } \\
\text { housing and an adequate } \\
\text { standard of living, the right } \\
\text { to social protection, health, } \\
\text { medical care and } \\
\text { education. }\end{array}$ \\
\hline $\begin{array}{l}\text { MYKOLAIV } \\
\text { OBLAST }\end{array}$ & $\begin{array}{l}\text { Comprehensive program } \\
\text { of social protection } \\
\text { "Turbota" for the period up } \\
\text { to } 2020 \text { https://www.mk- } \\
\text { oblrada.gov.ua/oblasni- } \\
\text { programy }\end{array}$ & $\begin{array}{l}\text { Social and material } \\
\text { assistance to internally } \\
\text { displaced persons. }\end{array}$ \\
\hline $\begin{array}{c}\text { SUMY } \\
\text { OBLAST }\end{array}$ & $\begin{array}{l}\text { Regional comprehensive } \\
\text { program of social } \\
\text { protection of the } \\
\text { population for } 2017-2021 \\
\text { http://sm.gov.ua/uk/2012- } \\
\text { 02-03-08-03-13.htm }\end{array}$ & $\begin{array}{l}\text { Social and material } \\
\text { assistance to internally } \\
\text { displaced persons. }\end{array}$ \\
\hline
\end{tabular}

Some of them received financial assistance from international sponsors or were executive partners of international organizations. In particular, it is worth mentioning such organizations as: Caritas of Ukraine, the community of volunteers "Vidnovlennya Skhid», Vostok SOS, Krym SOS, Donbass SOS, NUO «Stantsiya Kharkiv», coordination center IDP «Dopomoha Dnipra», Kryms'ka diaspora, Rada hromads'kykh initsiatyv, Hromads'ka initsiatyva, HO Pereselenets', Blahodiynyy Fond «Ksena». Obviously, all these organizations differently prioritized the areas of assistance to internally displaced persons (counseling services, psychological support, material assistance, development of state policy in relation to this category of citizens), and consequently, they participated in different ways in ensuring professional rehabilitation of internally displaced unemployed persons. An analysis of the practice of volunteer organizations confirmed that they sometimes lacked a systematic approach and qualified psychologists.

One of the important issues in the focus of scientific theorists and practitioners was the determination of the forms and methods of psychological support for internally displaced unemployed persons, 
which should have contributed to their professional readaptation. In particular, I. Drozdova suggests identifying the following main areas of work of a psychologist with forced migrants.

1. Psychological support of forced migrants, which provides neutralization of the negative impact of traumatic factors, reduction of emotional stress, aggression.

2. Assessment of their psychoemotional state. Forced migration is a traumatic, extraordinary situation for a person, therefore emotional reactions, feelings and actions of people is a kind of reaction to circumstances. The psychologist must assess the state of the emotional-volitional and cognitive spheres of the personality, the presence of painful mental conducts, adaptability in social relations, the ability to control own behavior and maintain a certain level of activity to achieve goals.

3. Correction of disorders in the psycho-emotional state of forced migrants: since they can lead to global personality problems, timely correction of affective, motivational, cognitive and behavioral disorders is important.

4. Development of the adaptive potential of forced migrants. Serious problems also appear in interpersonal relations: in interaction with representatives of the local community, partly in marital relations and relations with children. To integrate into a new environment, one needs to show empathy and tolerance, the ability to accept and provide support, and to constructively resolve conflict situations.

5. Preventive activity of a psychologist. Forced migration involves the interaction of migrants with special state services, they provide assistance to internally displaced persons. Specialists of these services also need psychological preparation for working with this category of people.

6. The research aspect of the work of a psychologist. When working with internally displaced persons, it is necessary to take into account the specifics of a particular migration situation, its social and political determinants, as the peculiarities of the psycho-emotional state of migrants may be related to the specifics of the migration situation (Drozdova, 2016). 
As a result of the analysis of scientific sources and practical experience of this category of population, the expediency is confirmed the use of methods and techniques of psychotherapy that help a person to get out of a depressed state, as well as personalityoriented technologies of professional development of a person (psychological counseling on problems of social and professional development, trainings of personal and professional development and self-development, psychotechnics of positive thinking, technologies of formation of psychological self-competence, design alternative scenarios of professional life, trainings to improve social and professional competence, trainings of self-regulation of emotional flax-volitional sphere and personal self-healing, monitoring of social and professional development), the purpose of which is to promote increased self-confidence, to overcome feelings of anxiety. Gaming technologies were also effective, consisting of a variety of exercises that were carried out both individually and within groups; psychological actions and role-playing games.

Psychologists note that partly unemployed internally displaced persons experience anxiety and insecurity in their own future, therefore, in the context of psychological programs, it is advisable to pay attention to the style of their response to life situations and strategies for its solution; features of emotional and volitional regulation; tolerance of uncertainty; actualization of adaptive potential (the formation of communicative abilities, moral normativity and neuropsychic stability); the development of professional motives (activity, self-realization, the desire to learn new things and achieve success).

Analysis of scientific sources and practical experience gives reason to conclude that, provided systemic, integrated, qualified psychological assistance is quite successfully returning internally displaced persons to normal life, their integration into a new system of relations, including professional reintegration.

Conclusions. So, professional reintegration is a gradual adaptation of a person which already has experience of professional activity, to its new conditions, in which there is a restructuring of the needs-motivational sphere of personality. An indicator of effective 
professional readaptation is the harmonious relationship between adaptive potential of the individual and new conditions of professional activity. It was determined that people belonging to the category of internally displaced unemployed persons experience difficulties in adapting to new socioeconomic conditions, they are predominantly passive and expectant.

It was found that a number of state, regional and district programs were aimed at helping internally displaced persons in general and psychological support in particular, the development of which took place in accordance with the sociopsychological factors of professional readaptation of this category of the population and its level of disadaptation. This problem was in the focus of attention of a number of volunteer organizations, which operated mainly in regions of mass concentration of internally displaced persons, but their psychological support was characterized by the absence of an integrated systematic approach and the absence of competent specialists.

It was determined that internally displaced persons need psychotherapeutic help and professional consultations of psychologists to overcome crisis situations in life. The effectiveness of such forms and methods of psychological support as special trainings and game technologies, the purpose of which is to overcome depressive states of personality, increase self-confidence, stimulate personal and professional development, has been proven.

We see prospects for further research in the development of a model for the professional rehabilitation of internally displaced unemployed persons in the formulation of detailed practical recommendations for specialists providing psychological support to this category of population.

\section{References}

Baklytskyi, I. O. (2008). Psykholohiia pratsi [Psychology of work]. Kyiv: Znannia. [in Ukrainian].

Blynova, O. Ye. (2016). Sotsialno-psykholohichna adaptatsiia vymushenykh mihrantiv: pidkhody i problemy vyvchennia fenomena akulturatsii [Socio-psychological adaptation of forced migrants: approaches and problems of studying the phenomenon of acculturation]. Naukovyi 
visnyk Khersonskoho derzhavnoho universytetu. Seriia: Psykholohichni nauky - Scientific Bulletin of Kherson State University. Series: Psychological Sciences, 3 (1), 111-117. [in Ukrainian].

Valo, L. I. (2017). Osoblyvosti sotsialnoi readaptatsii pedahohiv peredpensiinoho viku: empirychnyi aspekt doslidzhennia [Features of social readaptation of teachers of pre-retirement age: an empirical aspect of the study]. Psykholohichni nauky: problemy $i$ zdobutky - Psychological sciences: problems and achievements, 1, 26-38. [in Ukrainian].

Drozdova, I. I. (2016). Problemy i metody organizacii psihologicheskoj pomoshhi vynuzhdennym migrantam (iz opyta raboty psihologa obshhestvennoj organizacii). [Problems and Methods of Organization of Psychological Assistance to Forced Migrants (from experience of psychologist of public organization)] Social'nopsihologicheskaja adaptacija migrantov $v$ sovremennom mire- SocioPsychological Adaptation of Migrants in the Modern World (pp. 60-64). Penza: Izd-vo PGU [in Russian].

Krushelnytska, O. V., Melnychuk, D. P. (2005). Upravlinnia personalom [Management of the personnel]. Kyiv: Kondor. [in Ukrainian].

Gajda, J. (2015). Social and Professional Adaptation of Employees as a Main Factor in Shaping Working Conditions. Journal of US-China Public/Administration, 12(10), 789-795.

Zauner, J. (1967). Professional readaptation through clinical psychotherapy: results of a follow-up study. Psychotherapy and Psychosomatics, 15(1), 71-75.

Original manuscript received December, 112019

Revised manuscript accepted December, 21, 2019 